\title{
Effect of replacement of vanadium by iron on the electrochemical behaviour of titanium alloys in simulated physiological media ${ }^{(\cdot)}$
}

\author{
D. Mareci*, V. Lucero** and J. Mirza**
}

Abstract

\begin{abstract}
The electrochemical behaviour of Ti6Al4V, Ti6Al3.5Fe and Ti5Al2.5Fe alloys has been evaluated in Ringer's solution at $25^{\circ} \mathrm{C}$. The effect of the substitution of vanadium in Ti6Al4V alloy has been specifically addressed. The evaluation of the corrosion resistance was carried out through the analysis of the open circuit potential variation with time, potentiodynamic polarization curves, and electrochemical impedance spectroscopy (EIS) tests. Very low current densities were obtained (order of $\mathrm{nA} / \mathrm{cm}^{2}$ ) from the polarization curves and EIS, indicating a typical passive behaviour for all investigated alloys. The EIS results exhibited relative capacitive behaviour (large corrosion resistance) with phase angle close to $-80^{\circ}$ and relative high impedance values (order of $105 \Omega \cdot \mathrm{cm} 2$ ) at low and medium frequencies, which are indicative of the formation of a highly stable film on these alloys in Ringer's solution. In conclusion, the electrochemical behaviour of Ti6Al4V is not affected by the substitution of vanadium with iron.
\end{abstract}

\section{Efecto de la sustitución de vanadio por hierro en el comportamiento electroquímico de aleciones de titanio en un medio fisiológico simulado}

\begin{abstract}
Resumen
El comportamiento electroquímico de las aleaciones Ti6Al4V, Ti6Al3.5Fe y Ti5Al2.5Fe fue evaluado en una disolución Ringer a $25^{\circ} \mathrm{C}$. Se ha estudiado especialmente el efecto de la sustitución del vanadio en la aleación Ti6Al4V. La evaluación de la resistencia a la corrosión se ha llevado a cabo a través del análisis de la variación del potencial de un circuito abierto con el tiempo, las curvas de polarización potenciodinámicas y los ensayos de espectroscopía de impedancia electroquímica (EIS). Se han obtenido densidades de corriente muy bajas (del orden de $\mathrm{nA} / \mathrm{cm}^{2}$ ) en las curvas de polarización y EIS, indicando un comportamiento pasivo típico para todas las aleaciones investigadas. Los resultados de la EIS mostraron un comportamiento capacitivo relativo (gran resistencia a la corrosión) con ángulos de fase próximos a $-80^{\circ}$ y valores de impedancia relativamente altos (del orden de $10^{5} \Omega \cdot \mathrm{cm}^{2}$ ) a frecuencias bajas e intermedias, lo cual es indicativo de la formación de una película altamente estable sobre estas aleaciones en solución Ringer. En resumen, el comportamiento electroquímico de Ti6Al4V no se ve afectado si se sustituye el vanadio por el hierro.
\end{abstract}

Palabras clave

Titanio; Aleaciones; Biocompatibilidad; Corrosión; Polarización; Impedancia.

\section{INTRODUCTION}

Since the 1980s, the titanium alloys are intensively applied in the manufacturing of biomedical devices where the most important factors are, firstly, biocompatibility, corrosion resistance, mechanical behaviour and osseointegration (facility to bone ingrowths or fixes in the metal implant with the patient's bone structure) ${ }^{[1-6]}$.

Corrosion resistance is a critical property for this kind of application because physiological fluids are chloride containing solutions, with concentration of approximately $1 \%$ wt. NaCl. Furthermore, corrosion products are largely responsible for limited biocompatibility and can produce undesirable reactions in implant-adjacent tissues. Corrosion resistance plays a decisive role in determining the successful use of metal alloys as biomaterials.

Titanium is difficult to cast because it has a high melting point value $\left(1,682^{\circ} \mathrm{C}\right)$ and presents tendency to contamination due to an increased reactivity.

\footnotetext{
(•) Trabajo recibido el día 25 de septiembre de 2007 y aceptado en su forma final el día 28 de julio de 2008.

* Technical University of lasi, Faculty of Chemical Engineering, D. Mangeron n71, 700050, lasi, Romania.

** Las Palmas de Gran Canaria University, Dept. Mechanical Engineering, 35017 Las Palmas de Gran Canaria, Spain.
} 
In order to decrease the quantity of melting impurities and to increase the wear resistance, titanium is alloyed with various elements. Titanium alloys having biphasic structure $(\alpha+\beta)$ are used on a large scale. Among the alloying elements, $\mathrm{Al}$ is $\alpha$-stabilizer and it dissolves in the $\beta$-phase increasing the stability domain of this phase. Mo, $\mathrm{V}, \mathrm{Nb}, \mathrm{Ta}$ are $\beta$-stabilizers elements which decrease the temperature of allotropic transformation, forming continuous series of solid solutions with $\beta$-Ti but their solubility in $\alpha$-Ti is limited. Fe is a $\beta$-stabilizer element, which forms with the titanium eutectic and eutectoids phases.

Ever since the pioneer metal alloys have been use as biomaterials, lack of biocompatibility has been extensively reported and research on improved materials with appropriate mechanical behaviour and adequate biocompatibility was developed. The Ti6Al4V alloy was the first titanium alloy registered as implant material ${ }^{[7]}$. Further studies have indicated that vanadium, used to stabilize the $\beta$-phase, produces harmful oxides for the human body ${ }^{[8 \text { and } 9]}$. The toxicity of vanadium pushed forward the search for materials to replace Ti6A14V. It has been suggested by Khan et al. ${ }^{[10]}$ that $\mathrm{Ti} 6 \mathrm{Al} 7 \mathrm{Nb}$ can be a better alternative to Ti6Al4V because of its corrosion resistance and resistance to loss the mechanical properties with changes in $\mathrm{pH}$ in simulated body fluid environment.

Electrochemical behaviour of titanium and its alloys has been reported based on biocompatibility in various physiological mediums. Pan et al. ${ }^{[11]}$ investigated the electrochemical behaviour of commercially pure titanium in phosphate-buffered saline with and without $\mathrm{H}_{2} \mathrm{O}_{2}$ additions. Gonzalez and Mirza-Rosca ${ }^{[12]}$ investigated the electrochemical behaviour of titanium and several of its alloys in Ringer's solution using the electrochemical impedance spectroscopy. Silva et al. ${ }^{[13]}$ carried out electrochemical characterization of oxide films formed on Ti6Al4V alloy implanted with Ir in phosphatebuffered saline solution.

In the present study, the electrochemical and corrosion behaviour of Ti6Al4V has been compared with that of titanium alloys in which vanadium was replaced with Fe. The Ti5Al2.5Fe alloy was evaluated because it has been suggested as a candidate human body implant material ${ }^{[14]}$.

Two electrochemical techniques were used for this purpose: potentiodynamic polarization and electrochemical impedance spectroscopy (EIS). Standard corrosion parameters such as corrosion current density $\left(\mathrm{i}_{\text {corr }}\right)$, corrosion potential $\left(\mathrm{E}_{\text {corr }}\right)$ and polarization resistance $\left(R_{p}\right)$, were evaluated from these experiments.

\section{MATERIALS AND METHODS}

\subsection{Materials and sample preparation}

Titanium alloys were purchased from Rare and NonFerrous Metals Institute, Bucharest, as cast. The titanium-based materials used in this work were: Ti6Al3.5Fe, Ti5Al2.5Fe and Ti6Al4V alloys.

The testing medium was an aerated Ringer's solution whose composition is: $\mathrm{NaCl}-8.6 \mathrm{~g} / \mathrm{l}, \mathrm{KCl}$ $-0.3 \mathrm{~g} / \mathrm{l}, \mathrm{CaCl}_{2}-0.48 \mathrm{~g} / \mathrm{l}$.

The $\mathrm{pH}$ was measured with a multiparameter analyzer CONSORT 831C. The $\mathrm{pH}$ of this reference solution was 6.5.

From each material were cut three samples of 1 $\mathrm{cm}^{2}$ size and brass nut was attached to each sample using conductive paint to ensure electrical conductivity. The assembly was then embedded into an epoxy resin disk. Then the samples were ground with $\mathrm{SiC}$ abrasive paper up to 1000 grit, final polishing was done with $1 \mu \mathrm{m}$ alumina suspension. The samples were degreased with ethyl alcohol followed by ultrasonic cleaning with deionised water and dried under a hot air stream.

\subsection{Microstructural characterisation}

The structural studies were performed with an optical microscope, Olympus PME 3-ADL. The microstructures were revealed by etching in $10 \% \mathrm{HF}+5 \%$ $\mathrm{HNO}_{3}$ solution for $3-5 \mathrm{~s}$ at $25^{\circ} \mathrm{C}$ and were analysed using Scion Image software.

\subsection{Potentiodynamic polarization studies}

For all the electrochemical tests, experiments were performed using an aerated Ringer's solution maintained at $25 \pm 1{ }^{\circ} \mathrm{C}$ as an electrolyte. The assembled specimen was placed in a glass corrosion cell, which was filled with freshly prepared electrolyte (within 24 h). A saturated calomel electrode (SCE) was used as the reference electrode and a platinum coil as the counter electrode.

The measurements were performed with a Princeton Applied Research potentiostat (Model 263 A) controlled by a personal computer and a specific software (PowerCorr, Princeton Applied Research).

For each specimen, $24 \mathrm{~h}$ of open circuit potential, $\mathrm{E}_{\mathrm{OC}}$, measurement was performed initially followed by the linear polarization measurement. Linear polarization was conducted from $\mathrm{E}_{\mathrm{OC}}-150 \mathrm{mV}$ to $\mathrm{E}_{\mathrm{OC}}+150 \mathrm{mV}$ at a scanning rate of $0.2 \mathrm{mV} / \mathrm{s}$, to 
identify the $b_{a}$ (Tafel slopes for the partial anodic processes) and $b_{c}$ (Tafel slopes for the partial cathodic processes), the $\mathrm{i}_{\text {corr }}$ (corrosion current density) and the $\mathrm{E}_{\text {corr }}$ (corrosion potential). It was then followed by the general polarization tests from $-600 \mathrm{mV}$ to $1200 \mathrm{mV}$ at a scanning rate of $0.5 \mathrm{mV} / \mathrm{s}$ for evaluating the stability of passivation. From the obtained anodic polarization curves, $\mathrm{i}_{\text {pass }}$ (passivation current density) was determined.

\subsection{Electrochemical impedance spec- troscopy studies (EIS)}

The electrochemical impedance spectroscopy (EIS) was performed $24 \mathrm{~h}$ after immersion in aerated solutions at the open circuit potential using a Princeton Applied Research potentiostate (Model 263 A) connected with a Princeton Applied Research 5210 lock-in amplifier.

The spectra were recorded in the $10^{-2} \mathrm{~Hz}$ to $10^{5}$ $\mathrm{Hz}$ frequency range. The applied alternating potential signal had an amplitude of $10 \mathrm{mV}$.

Data acquisition and analysis were performed with a personal computer. The spectra were interpreted using the ZSimpWin program. The programme uses a variety of electrical circuits to numerically fit the measured impedance data. The program is capable of conducting analysis of heavily convoluted frequency dispersion data by deconvoluting the complex response into those of simple subcomponents. This approach combined with the general nonlinear least squares fit procedure allowed us to construct equivalent circuit (EC), whose simulated responses fit well the actually measured data. Impedance data were represented in impedance amplitude and phase angle plots (Bode plots). The Bode representation shows the logarithm of the impedance modulus (Zmod) and phase angle as a function of the logarithm of the frequency. The frequency dependence of the phase angle indicates whether one or more time constants occur and can be used to determine the values of the parameters in the equivalent circuit (EC).

\subsection{SEM and XRD studies}

Surface morphology after the electrochemical treatments of the samples was studied with an research electronic microscope of Tesla BS 300 type.

XRD patterns were measured using a Philips Analytical PW3710 XPERT system with a Ni filter and $\mathrm{Cu} \mathrm{K \alpha}(\lambda 1.5418 \mathrm{~A})$ radiation $(40 \mathrm{kV}, 30 \mathrm{~mA})$ at $0.05^{\circ}$ steps at the rate of 10 s per step over the range $10^{\circ}<2 \theta<70^{\circ}$.

\section{RESULTS}

\subsection{Microstructural characterization}

Surfaces of the three alloys were characterized from the structural point of view. As cast, titanium-based materials have a structure that is determined by the cooling from $\alpha$-phase domain at a moderate cooling rate. The investigated titanium alloys have a Widmanstätten-type structure that consists of $\alpha$-phase lamellae. The optical images from figure $1 \mathrm{a}$ ), b) and c) show a basket weave morphology of $\alpha$-phase regardless of chemical compositions of titanium alloys.

In all the microstructures the, phase appears dark and the $\alpha$ phase light. All the studied alloys were alpha-beta alloys. Alpha was the dominant phase in all the alloys: $80.3 \%$ in Ti6Al4V, 78\% in Ti6Al3.5Fe and $84 \%$ in $\mathrm{Ti} 5 \mathrm{Al} 2.5 \mathrm{Fe}$.

In the case of the alloys with vanadium the width of the lamellas is bigger than in the case of the two alloys with iron; it can be supposed that this alloy is more susceptible to corrosion because the compositional difference across the grain boundaries is bigger and leads to the galvanic cell formation.

\subsection{Potentiodynamic polarization studies}

The metals immersed in an electrolytic environment generate an electric potential that varied with time. After a period of immersion it stabilises around a stationary value. This potential may vary with time because changes in the nature of the surface of the electrode occur (oxidation, formation of the passive layer or immunity). The open circuit potential is used as a criterion for the corrosion behaviour. The open circuit potential is a parameter whish indicates the thermodynamically tendency of a material to electrochemical oxidation in a corrosive medium.

Figure 2 shows the $\mathrm{E}_{\mathrm{OC}}$ curves for all the three samples immersed in Ringer's solution at $25^{\circ} \mathrm{C}$.

Open circuit potential variation is similar for all the samples. Initially, the potential of the two titanium-iron based alloys presents approximately the same value: $-547 \mathrm{mV}$ for Ti6Al3.5Fe and -540 $\mathrm{mV}$ for Ti5Al2.5Fe while Ti6Al4V alloy has the most negative potential: $-667 \mathrm{mV}$.

During the first moments of immersion, an abrupt $\mathrm{E}_{\mathrm{OC}}$ displacement towards positive potentials was noticed in figure 2 during a period of $1-2 \mathrm{~h}$. This initial 
EFFECT OF REPLACEMENT OF VANADIUM BY IRON ON THE ELECTROCHEMICAL BEHAVIOUR OF TITANIUM ALLOYS IN SIMULATED PHYSIOLOGICAL MEDIA EFECTO DE LA SUSTITUCIÓN DE VANADIO POR HIERRO EN EL COMPORTAMIENTO ELECTROQUÍMICO DE ALECIONES DE TITANIO EN UN MEDIO FISIOLÓGICO SIMULADO

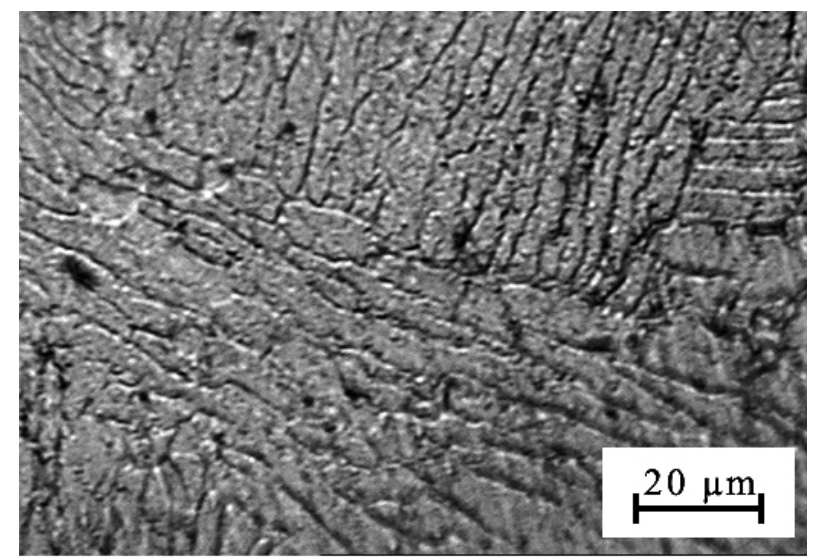

a)

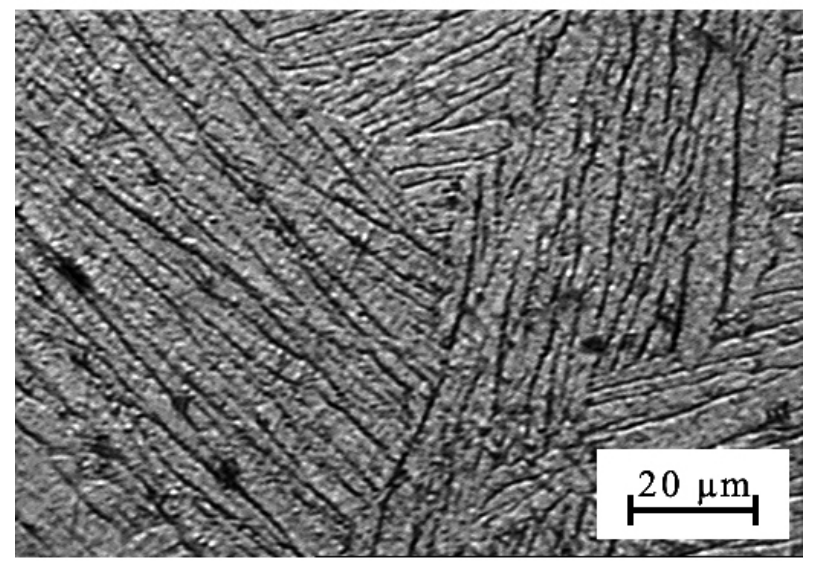

b)

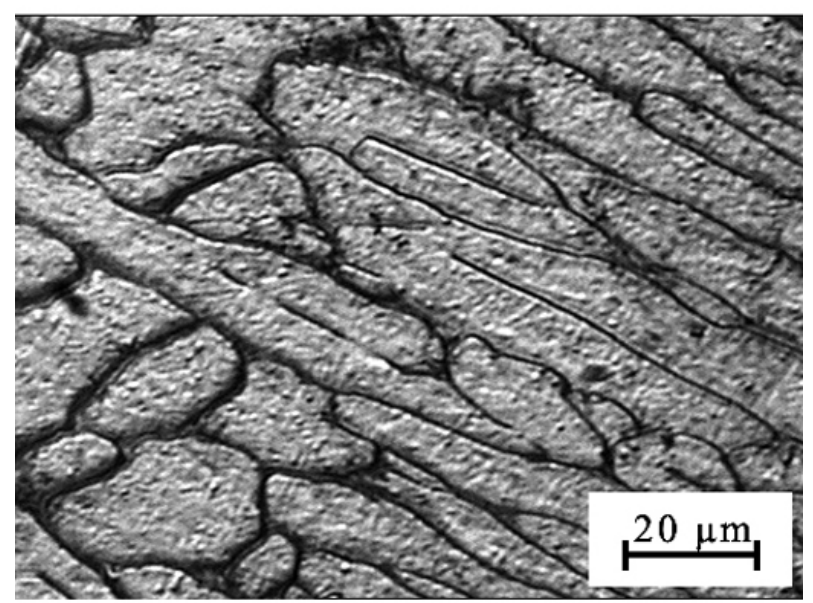

c)

Figure 1. Metalographic microscopy images for: a) Ti5Al2.5Fe, b) Ti6Al3.5Fe, c) Ti6Al4V. The samples were etched using $10 \% \mathrm{HF}+5 \%$ $\mathrm{HNO}_{3}$ solution at $25^{\circ} \mathrm{C}$.

Figura 1. Imagenes de microscopia metalografica para: a) Ti5Al2.5Fe, b) Ti6Al3.5Fe, c) Ti6Al4V. Las muestras se han atacado con disolucion 10 $\% \mathrm{HF}+5 \% \mathrm{HNO}_{3}$ a $25^{\circ} \mathrm{C}$.

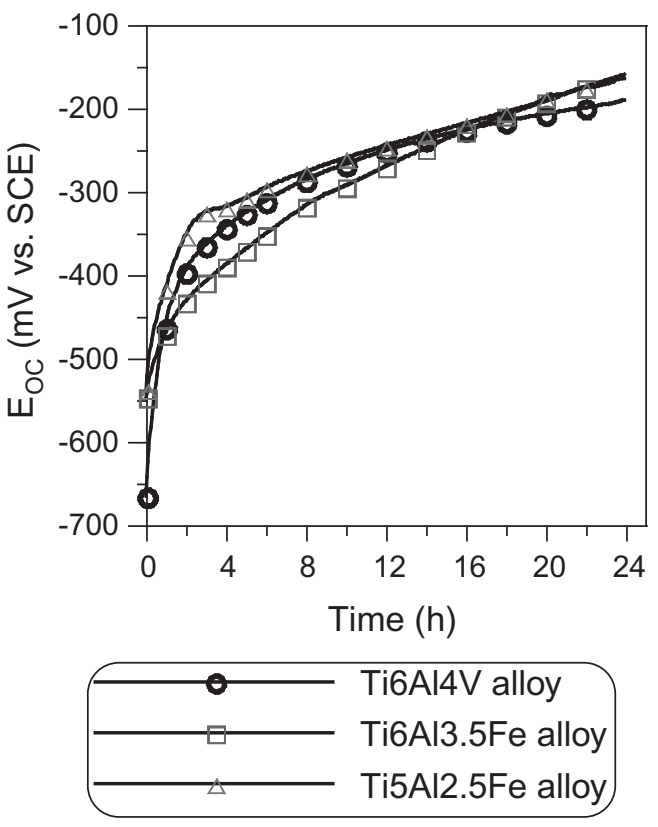

Figure 2. Variation of open circuit potential $\left(\mathrm{E}_{\mathrm{OC}}\right)$ with time for the three titanium alloys in Ringer's solution.

Figura 2. Variación del potencial en circuito abierto $\left(E_{O C}\right)$ con el tiempo para tres aleaciones de titanio en disolución Ringer.

increase seems to be related to the formation and thickening of the oxide film on the metallic surface, improving its corrosion protection ability ${ }^{[15-18]}$. Afterwards, the $\mathrm{E}_{\mathrm{OC}}$ increases slowly suggesting the growth of the film onto the metallic surface.

The studied samples did not exhibit potential drops associated with surface activation during 24 $\mathrm{h}$ exposure in the Ringer's solution. This kind of behaviour strongly suggests that the air-formed native oxide is thermodynamically resistant to chemical dissolution in Ringer's solution. Open circuit potential values are presented in table I at the beginning of the test and after $24 \mathrm{~h}$ of immersion in Ringer's solution.

Standard techniques were used to extract $\mathrm{E}_{\text {corr }}$ and $i_{\text {corr }}$ values from the potentiodynamic polarization plots. The Tafel slopes $\left(b_{a}\right.$ and $\left.b_{c}\right)$ were determined by fitting the theoretical polarisation curve to the experimental polarisation curve plotted in a range of $\pm 150 \mathrm{mV}$ vs. $\mathrm{E}_{\mathrm{OC}}$. The two Tafel slopes intercept at the point of the coordinates $\left(\mathrm{E}_{\text {corr }}, \mathrm{i}_{\text {corr }}\right)$. In most of the aerated neutral solutions the corrosion rate is controlled by the oxygen diffusion at the surface of the electrode when $b_{c}>>b_{a}$. This supposition is confirmed by the values presented in the table II with the exception of the Ti5Al2.5Fe alloy. The corrosion current density $\left(i_{\text {corr }}\right)$ is representative for the 
Table I. Open circuit potential values of the tested samples: initially and after $24 \mathrm{~h}$ of immersion in Ringer's solution

Tabla I. Valores de potencial de circuito abierto: inicial y después de $24 \mathrm{~h}$ de la inmersión de las muestras de aleación en disolución Ringer

\begin{tabular}{lcc}
\hline Alloy & $\begin{array}{c}\text { Open circuit } \\
\text { potential, } \\
\text { Initial }\end{array}$ & $\begin{array}{c}\mathrm{E}_{\mathrm{OC}} \\
\text { (mV vs. SCE) } \\
\text { After 24 h }\end{array}$ \\
\hline Ti6Al4V & $-667 \pm 15$ & $-192 \pm 6$ \\
Ti5Al2.5Fe & $-540 \pm 11$ & $-165 \pm 5$ \\
Ti6Al3.5Fe & $-547 \pm 12$ & $-161 \pm 5$ \\
\hline
\end{tabular}

degradation degree of the alloy. The average values $b_{a}, b_{c}, E_{\text {corr }}$ and $i_{\text {corr }}$ from three different polarization curves determined by the PowerCorr program are presented in Table II. The very low $i_{\text {corr }}$ values obtained for the three tested titanium alloys are typical of passive materials.

The corrosion current densities for all the alloys were of the same order of magnitude $\left(\mathrm{nA} / \mathrm{cm}^{2}\right): 210$ $\mathrm{nA} / \mathrm{cm}^{2}$ for Ti6Al4V alloy, $185 \mathrm{nA} / \mathrm{cm}^{2}$ for Ti6Al3.5Fe alloy and $165 \mathrm{nA} / \mathrm{cm}^{2}$ for Ti5Al2.5Fe alloy.

Figure 3 compares typical potentiodynamic curves in a semi-logarithmic version between $-600 \mathrm{mV}$ and $+1,200 \mathrm{mV}$ of the three titanium alloys tested in Ringer's solution aerated at $25^{\circ} \mathrm{C}$ after being immersed for $24 \mathrm{~h}$.

The nature of the potentiodynamic polarization curves indicated that all the samples have been passivated immediately after the immersion in the Ringer's solution; all three materials translated directly from the "Tafel region" into a stable passive state, without exhibiting a common active-passive transition.

For the potentials above approximately $100 \mathrm{mV}$ up to approximately $300 \mathrm{mV}$ all the three anodic

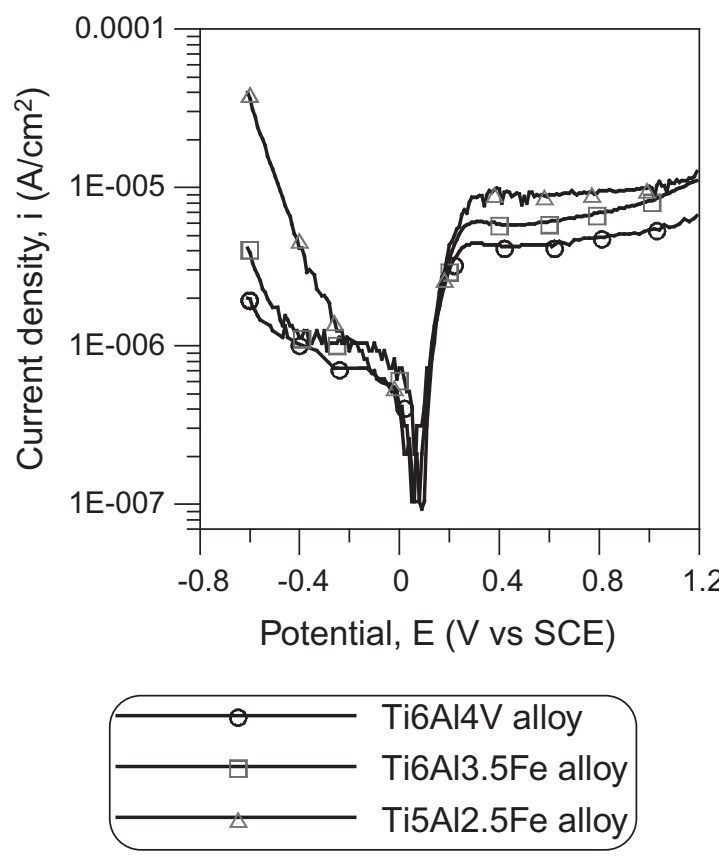

Figure 3. The potentiodynamic polarisation curves for titanium alloys after $24 \mathrm{~h}$ of immersion in Ringer's solution at $25^{\circ} \mathrm{C}$. Scan rate $0.5 \mathrm{mV} / \mathrm{s}$.

Figura 3. Curvas de polarización potenciodinámica para aleaciones de titanio después de 24 horas de inmersión en disolución Ringer a 25 ${ }^{\circ} \mathrm{C}$. Velocidad de barrido $0,5 \mathrm{mV} / \mathrm{s}$.

curves indicates behaviour typical of activation polarization showing a well defined linear range, suggesting conformity to the Tafel's Law. From 300 $\mathrm{mV}$ the curves show a passive behaviour. Passive current density $\left(i_{\text {pass }}\right)$ was also determined from the potentiodynamic anodic diagram of each specimen in Ringer's solution. Passive current densities $\left(i_{\text {pass }}\right)$ are obtained around the middle of the passive range and are listed in Table II. The lowest $\mathrm{i}_{\text {pass }}$ is observed on Ti6Al4V alloy (at about $4.5 \mu \mathrm{A} / \mathrm{cm}^{2}$ ) and the largest on the Ti5 Al2.5Fe (at about $8.5 \mu \mathrm{A} / \mathrm{cm}^{2}$ ). The

Table II. Electrochemical parameters of corrosion process after $24 \mathrm{~h}$ of immersion in Ringer's solution

Tabla II. Parámetros electroquímicos del proceso de corrosión después de 24 h de inmersión en disolución Ringer

\begin{tabular}{lccccc}
\hline \multicolumn{1}{c}{ Alloy } & $\mathrm{E}_{\text {corr }}(\mathrm{mV})$ & $\mathbf{b}_{\mathrm{a}}(\mathrm{mV} / \mathrm{dec})$. & $\mathbf{b}_{\mathrm{c}}(\mathrm{mV} / \mathrm{dec})$. & $\mathrm{i}_{\text {corr }}\left(\mathrm{nA} / \mathrm{cm}^{2}\right)$ & $\mathrm{i}_{\text {pass }}\left(\boldsymbol{\mu A} / \mathrm{cm}^{2}\right)$ \\
\hline Ti6Al4V & $78 \pm 10$ & $85 \pm 7$ & $\infty$ & $210 \pm 7$ & $4.5 \pm 0.3$ \\
Ti6Al3.5Fe & $96 \pm 18$ & $82 \pm 6$ & $\infty$ & $195 \pm 10$ & $6.3 \pm 0.3$ \\
Ti5Al2.5Fe & $75 \pm 15$ & $90 \pm 10$ & $250 \pm 10$ & $185 \pm 10$ & $8.5 \pm 0.5$ \\
\hline
\end{tabular}


EFFECT OF REPLACEMENT OF VANADIUM BY IRON ON THE ELECTROCHEMICAL BEHAVIOUR OF TITANIUM ALLOYS IN SIMULATED PHYSIOLOGICAL MEDIA EFECTO DE LA SUSTITUCIÓN DE VANADIO POR HIERRO EN EL COMPORTAMIENTO ELECTROQUÍMICO DE ALECIONES DE TITANIO EN UN MEDIO FISIOLÓGICO SIMULADO

passive current densities $\left(i_{\text {pass }}\right)$ for all three alloy samples are higher than corrosion current densities $\left(\mathrm{i}_{\text {corr }}\right)$ and suggest that the protective Ti oxide film can be more defective ${ }^{[19 \text { and } 20]}$. From the polarization curves it was found that all the alloys are maintained in their passive state at $1.2 \mathrm{~V}$ potential too. No breakdown was observed for any of the alloys.

No significant differences were found in $\mathrm{E}_{\text {corr }}, \mathrm{i}_{\text {corr }}$ or $\mathrm{i}_{\text {pass }}$ for all the samples. The results indicate that the polarization curves behaviour of the Ti6 $613.5 \mathrm{Fe}$ and Ti5Al2.5Fe alloys resembles that of the Ti6Al4V alloy. These alloys had a good corrosion resistance within the potential range used in this study.

Figure 4 shows the SEM images of Ti6Al4V and Ti5A12.5Fe alloys after the electrochemical treatments. After electrochemical treatments salt depositions were formed on the surface of the alloy. The Ringer's solution contains calcium ion, which generally precipitates on titanium alloys surface. This supposition is confirmed by XRD spectra, presented in figure 5 from Ti5 Al2.5Fe alloy after $24 \mathrm{~h}$ immersion in Ringer's solution and electrochemical treatments.

\subsection{Electrochemical impedance spec- troscopy (EIS) studies}

The corrosion resistance can also be estimated by means of the impedance method known as Electrochemical Impedance Spectroscopy (EIS). This technique requires minimal invasive procedures, neither the oxidation nor the reduction was forced

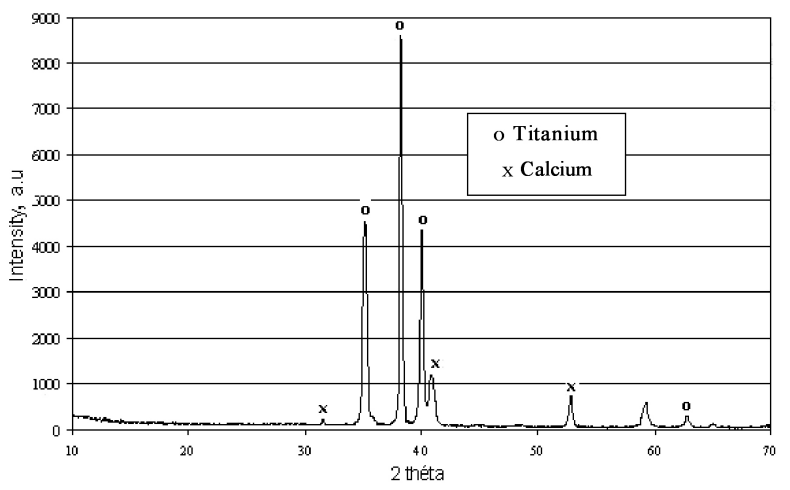

Figure 5. XRD pattern of the Ti5Al2.5Fe alloy surface after $24 \mathrm{~h}$ immersion in Ringer's solution and electrochemical tests.

Figura 5. Difractograma de Rayos $X$ en la superficie de la aleación Ti5Al2.5Fe después de $24 \mathrm{~h}$ de inmersión en disolución Ringer y ensayos electroquímicos.

to take place in the open circuit mode. From the EIS data we can obtain information about the passive film dissolution (the rate and type of the control) and the passive film characteristics (film thickness, passive film dielectric constant, diffusion coefficient of the diffusing species etc.).

Figures 6 and 7 shows Bode diagrams (Phase angle vs. $\log$ Frequency and $\mathrm{Z}$ modulus vs. $\log$ Frequency) of the titanium alloys at the open circuit potential after $1 \mathrm{~min}$ and $24 \mathrm{~h}$ respectively, of immersion in Ringer's solution at $25^{\circ} \mathrm{C}$.
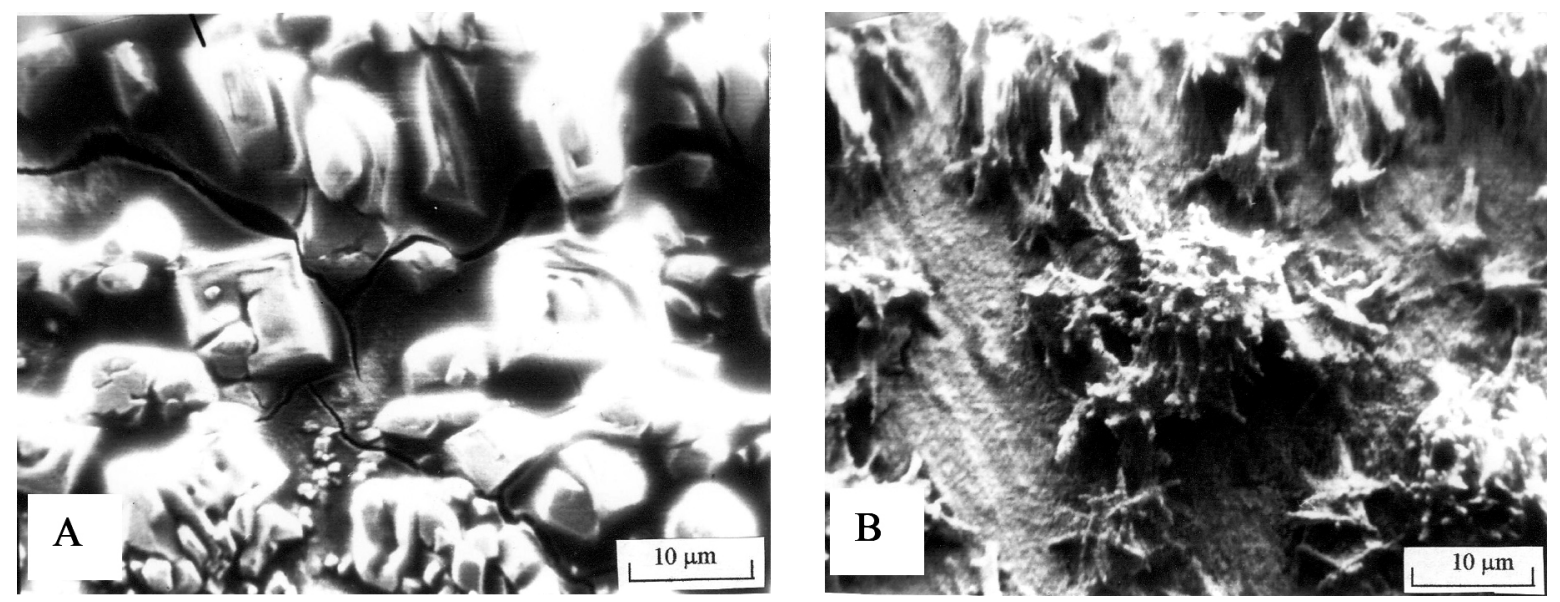

Figure 4. The salts depositions on the surfaces of the: a) Ti5Al2.5Fe alloy, b) Ti6Al4V alloy, after polarization tests from $-600 \mathrm{mV}$ to $1,200 \mathrm{mV}$ at a scanning rate of $0.5 \mathrm{mV} / \mathrm{s}$.

Figura 4. Las deposiciones de sales sobre la superficie de: a) aleacion Ti5A12,5Fe, b) aleacion Ti6Al4V, después de los ensayos de polarización desde $-600 \mathrm{mV}$ hasta $1.200 \mathrm{mV}$ a una velocidad de barrido de $0,5 \mathrm{mV} / \mathrm{s}$. 


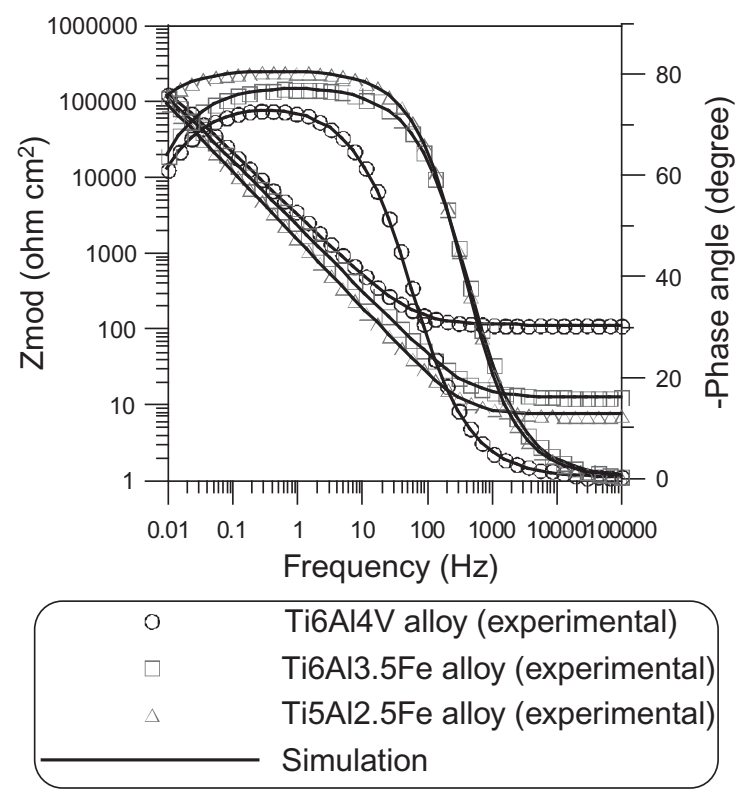

Figure 6. Bode plots of tested materials recorded at open circuit potential after immersion for $1 \mathrm{~min}$ in Ringer's solution at $25^{\circ} \mathrm{C}$.

Figura 6. Graficas Bode de los materiales ensayados a potencial de circuito abierto después de la inmersión durante 1 min en disolución Ringer a $25^{\circ} \mathrm{C}$.

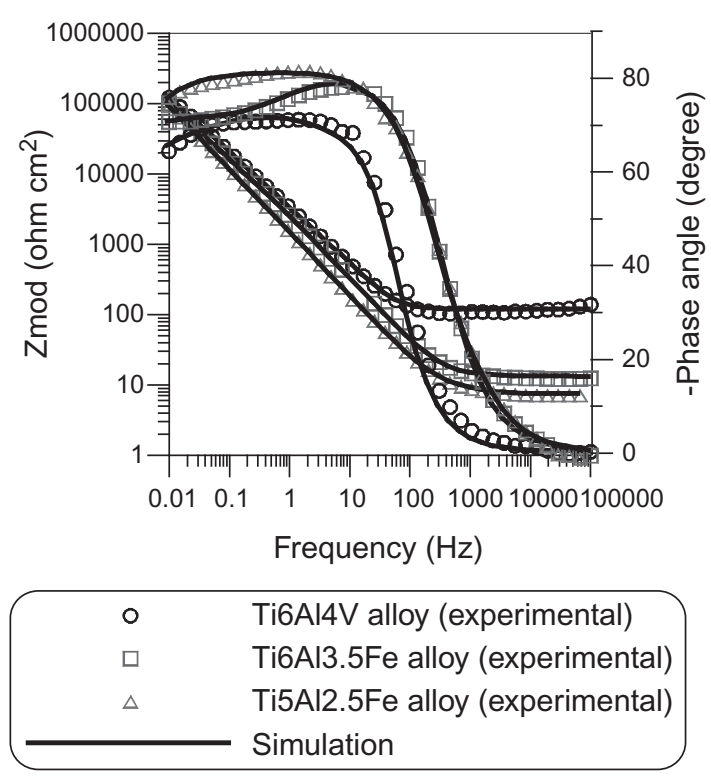

Figure 7. Bode plots of tested materials recorded at open circuit potential after immersion for $24 \mathrm{~h}$ in Ringer's solution at $25^{\circ} \mathrm{C}$.

Figura 7. Graficas Bode de los materiales ensayados registrados en potencial de circuito abierto después de la inmersión durante 24 h en disolución Ringer a $25^{\circ} \mathrm{C}$.
From the Bode spectra it is possible to observe the presence of a compact passive film if: (a) the phase angle is close to $-90^{\circ}$ over a wide frequency range, and (b) if the spectrum shows linear portions at intermediate frequency.

From figure 6 , the phase angle observed at low frequency for immediate immersion $(1 \mathrm{~min})$ was nearly $-60^{\circ}$. However, at intermediate frequency, the phase angle shifted to $80^{\circ}$ and remained constant over a wide range of frequency, indicating a near capacitive response for all the alloys. The high impedance values and phase angle of $-80^{\circ}$ are indicative of a single thin passive oxide film present on the surface at $1 \mathrm{~min}$ of immersion. The phase angles approaching $-80^{\circ}$ in a large frequency range are characteristic of a compact passive film ${ }^{[12]}$.

After $24 \mathrm{~h}$ of immersion, at low frequency, the phase angle values were shifted to $-70^{\circ}$, but there wasn't a significant difference in the response at medium frequencies.

For the interpretation of the electrochemical behaviour of a system from EIS spectra, an appropriate physical model of the electrochemical reactions occurring on the electrodes is necessary. The electrochemical system may be represented by an equivalent circuit (EC). An EC consists of various arrangements of resistances, capacitors and other circuit elements, and provides the most relevant corrosion parameters applicable to the substrate/electrolyte system. The usual guidelines for the selection of the best-fit EC were followed:

- a minimum number of circuit elements were to be employed;

- the -2 error was suitably low, and the error associated with each element were up to $5 \%$.

The impedance spectra were fitted using the ZsimpWin software. The results of the analysis are shown in Table III. Generally, for $\mathrm{TiO}_{2}$ films a

Table III. Electrical parameters of the proposed equivalent circuit obtained for the all studied samples at 1 minute of immersion in Ringer's solution

Tabla III. Parámetros eléctricos del circuito equivalente propuesto para las muestras estudiadas después de 1 minuto de inmersión en disolución Ringer

\begin{tabular}{lccc}
\hline \multicolumn{1}{c}{ Alloy } & $\begin{array}{c}\mathbf{R}_{1} \\
\left(\mathbf{c m}^{2}\right)\end{array}$ & $\mathbf{n}_{1}$ & $\begin{array}{c}10^{5} \mathrm{CPE}_{1} \\
\left(\mathbf{S ~ s}^{\mathbf{n}} \mathbf{~ c m}^{-2}\right)\end{array}$ \\
\hline Ti6Al4V & $1.510^{5}$ & 0.85 & $6.6 \pm 0.2$ \\
Ti5AI2.5Fe & $1.510^{5}$ & 0.88 & $8.1 \pm 0.2$ \\
Ti6Al3.5Fe & $1.610^{5}$ & 0.86 & $7.2 \pm 0.2$ \\
\hline
\end{tabular}


distributed relaxation feature is commonly observed. Due to this fact, in this study a constant phase element (CPE) was used for data analysis instead of an ideal capacitor. Impedance of $\mathrm{CPE}$ is given by $\mathrm{Z}_{\mathrm{CPE}}$ $=1 /\left[Q(j w)^{n}\right]$ where $Q$ is the combination of properties related to both the surfaces and electroactive species independent of frequency; $\mathrm{n}$ is related to a slope of the $\lg \mathrm{Zmod}$ vs $\lg$ Frequency in Bode-plots, $\omega$ is the angular frequency and $\mathrm{j}$ is imaginary number ()$. \mathrm{Q}$ is an adjustable parameter used in the fitting routine: when the value of $\mathrm{n}$ is equal to 1 , the CPE acts as a pure capacitor ${ }^{[21]}$.

Gonzalez and Mirza Rosca ${ }^{[12]}$ proposed $\mathrm{R}_{\mathrm{s}}\left(\mathrm{CPE}_{1} \mathrm{R}_{1}\right)$ as EC model to fit the EIS data in case of a single passive film present on the metal surface. Similarly, in the EC seen in figure 8 a) for titanium alloys at 1 min of immersion in Ringer's solution, consists of the following elements: $\mathrm{R}_{\mathrm{sol}}$ - ohmic resistance of the electrolyte, $\mathrm{CPE}_{1}$ - constant phase element of the double layer and $\mathrm{R}_{1}$ - resistance of the barrier layer. From Table III, it can be seen that the values of $\mathrm{n}$ were close to one $(n>0.85)$ for all titanium alloys at 1 min of immersion in Ringer's solution. This indicated a near ideal capacitance of the passive films formed on the titanium alloys.

The EC shown in figure 8 a) did not shows a good fit of the experimental results for the titanium alloys at $24 \mathrm{~h}$ of immersion in Ringer's solution. As the immersion time increased $(24 \mathrm{~h})$, the EC used for titanium alloys (Figure $8 b)$ was $\mathrm{R}_{\text {sol }}\left(\mathrm{R}_{1}\left(\mathrm{CPE}_{1}\left(\mathrm{R}_{2} \mathrm{CPE}_{2}\right)\right)\right.$, where $\mathrm{CPE}_{1}$ represents the constant phase element of the outer layer and $\mathrm{CPE}_{2}$ the constant phase element of the inner layer, $R_{1}$ and $R_{2}$ are the resistance of the outer layer (precipitate layer) and inner layer. The results of the fittings are presented in table IV.

Dissolution of the titanium oxide film in water from a thermodynamic point of view can be represented by reaction:

$$
\left\{\mathrm{TiO}_{2}\right\}_{\text {solid }}+2 \mathrm{H}_{2} \mathrm{O}=\mathrm{Ti}(\mathrm{OH})_{4(\mathrm{aq})}
$$

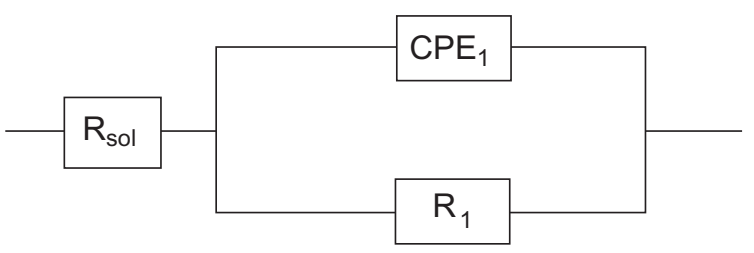

a)

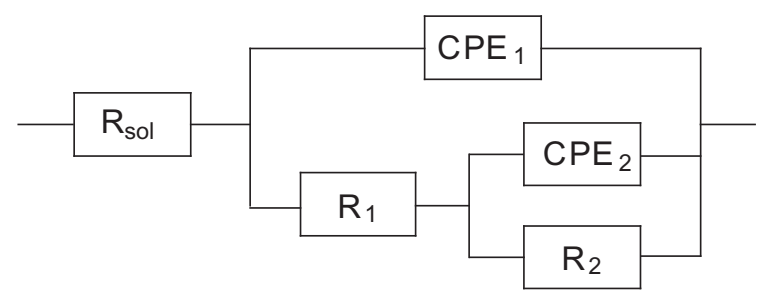

b)

Figure 8. Equivalent circuit (EC) used in the generation of simulated data for titanium alloys in Ringer's solution at different immersion time: (a) $1 \mathrm{~min}$ and (b) $24 \mathrm{~h}$.

Figura 8. Circuito equivalente (EC) utilizado en la generación de datos simulados para las aleaciones de titanio en disolucion Ringer a diferentes tiempos de inmersion: (a) 1 min y (b) $24 \mathrm{~h}$.

The majority of the dissolved species has been found to be uncharged ${ }^{[22]}$. The presence of a very small amount of charged corrosion products is expected to induce minimal unwanted biochemical reactions such as strong protein binding and unfolding:

$$
\begin{aligned}
& \left\{\mathrm{TiO}_{2}\right\}_{\text {solid }}+2 \mathrm{H}_{2} \mathrm{O}=\left[\mathrm{Ti}(\mathrm{OH})_{3}\right]_{(\mathrm{aq})}+\mathrm{OH}^{-} \\
& \left\{\mathrm{TiO}_{2}\right\}_{\text {solid }}+2 \mathrm{H}_{2} \mathrm{O}=\left[\mathrm{Ti}(\mathrm{OH})^{-}\right]_{(\mathrm{aq})}+\mathrm{H}_{3} \mathrm{O}^{-}
\end{aligned}
$$

The calcium ions present in the Ringer solution tends to attach to titanium oxide surface upon immersion:

Table IV. Electrical parameters of the proposed equivalent circuit obtained for the all studied samples

Tabla IV. Parámetros eléctricos del circuito equivalente propuesto por todas aleaciones de titanio estudiados

\begin{tabular}{lccccccc}
\hline Alloy & $\begin{array}{c}\mathbf{R}_{1} \\
\left(\Omega \mathbf{c m}^{2}\right)\end{array}$ & $\mathrm{n}_{1}$ & $\begin{array}{c}10^{5} \mathrm{CPE}_{1} \\
\left(\mathbf{S ~ s}^{\mathbf{n}} \mathbf{c m}^{-2}\right)\end{array}$ & $\begin{array}{c}\mathbf{R}_{2} \\
\left(\mathbf{W ~ c m}^{2}\right)\end{array}$ & $\mathrm{n}_{2}$ & $\begin{array}{c}10^{5} \mathrm{CPE}_{2} \\
\left(\mathbf{S ~ s}^{\mathbf{n}} \mathbf{c m}^{-2}\right)\end{array}$ & $\begin{array}{c}\mathbf{i}_{\text {corr }} \\
\left(\mathbf{n A} / \mathbf{c m}^{2}\right)\end{array}$ \\
\hline Ti6Al4V & $2.110^{3}$ & 0.9 & $2.6 \pm 0.1$ & $2.110^{5}$ & 0.7 & $4.6 \pm 0.2$ & $174 \pm 15$ \\
Ti5Al2.5Fe & $1.110^{3}$ & 0.92 & $6.1 \pm 0.3$ & $2.510^{5}$ & 0.75 & $6.7 \pm 0.3$ & $115 \pm 11$ \\
Ti6Al3.5Fe & $1.710^{3}$ & 0.9 & $7.2 \pm 0.3$ & $2.310^{5}$ & 0.72 & $2.7 \pm 0.2$ & $155 \pm 12$ \\
\hline
\end{tabular}




$$
\left\{\mathrm{TiO}_{2}\right\}_{\text {solid }}+\mathrm{Ca}_{(\mathrm{aq})}^{2+}=\left[\mathrm{TiO}^{-} \ldots \mathrm{Ca}_{(\mathrm{aq})}^{2+}\right]_{\mathrm{solid}}+\mathrm{H}_{(\mathrm{aq})}^{+}(4)
$$

The same value for $R_{\text {sol }}$, equal to $41 \pm \Omega$ and 35 $\pm 2 \mathrm{~W}$, was observed for all of the specimens after 1 min and $24 \mathrm{~h}$ of immersion and was not inserted in tables III and IV.

After $24 \mathrm{~h}$ of immersion large values of $\mathrm{R}_{2}$ at open circuit potential (order of $10^{5} \Omega \mathrm{cm}^{2}$ ) were obtained supporting the passivation of the titanium alloys in Ringer's solution. $R_{2}$ was greater than $R_{1}$ by a factor of nearly 100 , showing that the resistance of the passive film on the titanium alloys is due to the inner layer.

Polarization resistance $\left(R_{p}\right)$ is represented by the sum of the resistance of the inner layer and outer layer, $R_{1}+R_{2}$. A high $R_{p}$ value corresponds to a high resistance to passive dissolution. From the SternGeary equation ${ }^{[23]}$ :

$$
i_{\text {corr }}=\frac{b_{a} b_{c}}{2.3 R_{p}\left(b_{a}+b_{c}\right)}=\frac{B}{R_{p}}
$$

where: $b_{a}$ and $b_{c}$ are the Tafel slopes for the partial anodic and cathodic processes, respectively and $B$ is a constant:

$$
B=\frac{b_{a} b_{c}}{2.3\left(b_{a}+b_{c}\right)}
$$

The polarization resistance of the alloys after 24 $\mathrm{h}$ of immersion is large indicating a sufficient stability of titanium alloys in Ringer's solution. The corrosion current densities for the titanium alloys were of the same order of magnitude $\left(\mathrm{nA} / \mathrm{cm}^{2}\right)$ and are in agreement with the polarization data.

The exponents of the $\mathrm{CPE}_{1}, \mathrm{n}_{1}$, take values between 0.9 and 0.92 while the exponents of the $\mathrm{CPE}_{2}, \mathrm{n}_{2}$, are between 0.7 and 0.75 . The $\mathrm{n}$ values of nearly one suggest that the behaviour of outer layer approached that of an ideal capacitor.

The fitted circuit for the obtained impedance data has an error distribution less than $1 \%$ and the circuit showed a perfect fitting for titanium alloys data in Ringer's solution.

\section{DISCUSSIONS}

When an alloy is placed in a biological environment, an electrochemical interaction (corrosion) between the two takes place. The effect of this interaction may be manifested as: (1) release of soluble metallic ions into the environment; (2) formation of corrosion products on the alloy surface; or (3) a combination of both. These effects, depending on the altered alloy surface and/or the nature of released metallic ions, may trigger adverse biological reactions such as allergy ${ }^{[24]}$. For a specific environment, corrosion depends on the structure and the composition of the alloy. The titanium alloys of the present study have different compositions. All the studied alloys were alpha-beta alloys and have a Widmanstätten-type structure. Alpha was the dominant phase in all the alloys. The analysis of obtained results in all performed electrochemical tests indicates that all three Ti alloys behaved in a very similar way. The differences are rather small, and this can be ascribed to the fact that the passive film formed on these alloys is essentially of the same nature. The open circuit potential curves shown in figure 2 indicate that the potential of the $\mathrm{Ti}$ alloys in the Ringer's solution at $25^{\circ} \mathrm{C}$ increases rapidly with time and this initial increase seems to be related to the thickening of the oxide film improving its corrosion protection ability ${ }^{[25}$ and 26].

The very low corrosion current densities (order $10^{-7} \mathrm{~A} / \mathrm{cm}^{2}$ ) obtained for the three tested titanium alloys are typical of passive materials. The increase in current density with potential could occur if the increase in potential is accompanied by a corresponding thickening film, or could be due to the oxidation of $\mathrm{TiO}$ or $\mathrm{Ti}_{2} \mathrm{O}_{3}$ to $\mathrm{TiO}_{2}$ [19 and 20]. Nevertheless, it appears that the film formed above $300 \mathrm{mV}$ is different from that formed below this potential. Its higher $i_{\text {pass }}$ value indicates it is a more defective oxide.

High impedance values (order of $10^{5} \Omega \cdot \mathrm{cm}^{2}$ ) were obtained from medium to low frequencies for all $\mathrm{Ti}$ alloys suggesting a high corrosion resistance in the electrolyte. This result supports the passive behaviour of the alloys, indicated by the polarization curves and open circuit potential variation with time curves.

The EIS results indicated the presence of two layers after $24 \mathrm{~h}$ immersion for all three Ti alloys. According to the proposed model, the passive film consists of two layers, the inner barrier layer (titanium oxide) and the outer layer (precipitate layer). The resistance values, $R_{2}$, are significantly larger than the values associated to the precipitate layer as table IV shows. These results indicate that the protection provided by the passive layer is predominantly due to the inner layer.

\section{CONCLUSIONS}

The electrochemical techniques used in this investigation led to the following conclusions: 
EFFECT OF REPLACEMENT OF VANADIUM BY IRON ON THE ELECTROCHEMICAL BEHAVIOUR OF TITANIUM ALLOYS IN SIMULATED PHYSIOLOGICAL MEDIA EFECTO DE LA SUSTITUCIÓN DE VANADIO POR HIERRO EN EL COMPORTAMIENTO ELECTROQUÍMICO DE ALECIONES DE TITANIO EN UN MEDIO FISIOLÓGICO SIMULADO

- All three titanium alloys has provided a passive film formation during corrosion tests in Ringer's solution, which has been observed by the very low experimental current densities.

- The EIS spectra results indicated that the film formed on the titanium materials is composed of a bi-layered consisting of an inner barrier layer associated to high impedance and responsible for corrosion protection and an outer precipitate layer.

- These alloys exhibited good corrosion resistance within the potential range used in the present study.

- The electrochemical behaviour of the Ti5Al2.5Fe and Ti6Al3.5Fe alloys examined in the present study resembles that of Ti6Al4V alloy.

The EIS technique is a powerful method to characterize the influence of the alloying elements on corrosion behaviour.

\section{Acknowledgements}

The authors would like to acknowledge the financial support of this work by MEC (Ministerio de Educacion y Ciencia, Spain), Ref. NAN2006-27753-E.

\section{REFERENCES}

[1] J.R. Newman, D. Eylon and J.K. Thorne, Metals Handbook, ASM International, Metals Park, Ohio, USA, 1988, pp. 824.

[2] C. Eriksson, K. Ohlson, K. Richter, N. Billerdahl, M. Johansson and H. Nygren, J. Biomed. Mater. Res. 83A (2007) 1062-1069.

[3] E.B. Taddei, V.A.R. Henriques, C.R.M. Silva and C.A.A. Cairo, Mater. Sci. Eng. 24C (2004) 683-687.

[4] H.S. Kim, S.H. Lim, I.D. Yeo and W.Y. Kim, Mater. Sci. Eng. A 449-451 (2007) 322-325.

[5] Y. Mantani and M. Tajima, Mater. Sci. Eng. 442A (2006) 409-413.

[6] C.R.M. Afonso, G.T. Aleixo, A.J. Ramírez and R. Caram, Mater. Sci. Eng. C 27 (2007) 908-913.
[7] T. Akahori and M. Niinomi, Mater. Sci. Eng. A243 (1998) 237-243.

[8] M.A. Khan, R.L. Williams and D.F. Williams, Biomaterials 20 (1999) 631-637.

[9] T.I. Kim, T.H. Han, I.S. Lee, K.H. Lee, M.C. Shin and B.B. Choi, Bio-Med. Mater. Eng. 7 (1997) 253-263.

[10] M.A. Khan, R.L. Williams and d. F. Williams, Biomaterials 17 (1996) 212-217.

[11] J. Pan, D. Thierry and C. Leygraf, J. Biomed. Mater. Res. 28 (1994) 113-122.

[12] J.E.G. González, J.C. Mirza Rosca, J. Electroanal. Chem. 471 (1999) 109-115.

[13] T.M. Silva, J.E. Rito, A.M.P. Simoes, M.G.S. Ferreira, M. da Lunha Belo and K.G. Watkins, Electrochim. Acta 43 (1998) 203-211.

[14] J. Mathew Jr., Titanium: a Technical Guide, 2nd ed., ASM International, 2000, pp.143-282.

[15] S. Canary, N. Hersek, A. Culha and S. Bilgic, J. Oral Rehabil. 25 (1998) 759-764.

[16] T. Eliades, Int. J. Oral Maxillofac. Implants 12 (1997) 621-627.

[17] J. Gluszek, J. Masalski, P. Furman and K. Nitsch, Biomaterials 18 (1997) 789-794.

[18] S. P. Kedici, A. A. Aksut, M.A. Kilicarslan, G. Bayramoglu and K. Gokdemir, J. Oral Rehabil. 25 (1998) 800-808.

[19] S. Luiz de Assis, S. Wolynec and I. Costa, Electrochim. Acta 51 (2006) 1815-1819.

[20] A. Cremasco, W.R. Osorio, C.M.A. Freire, A. Garcia and R. Caram, Electrochim. Acta (2008) in press.

[21] I.C. Lavos-Valereto, S. Wolynec, I. Ramires, A.C. Guastaldi and I. Costa, J. Mater. Sci: Mater. Med. 15 (2004) 55-59.

[22] S.G. Steinemann, Periodontology, 17 (1998) 7-14.

[23] M. Stern and A. Geary, J. Electrochem. Soc. 104 (1957) 56-63.

[24] K. Merrit and S.A. Brown, Hypersensitivity to metallic biomaterials. In: D.F. Williams, editor. Systemic aspects of biocompatibility, vol. 2, Boca Raton, FL: CRC Press, 1981, pp. 33-48.

[25] I.C. Lavos-Valereto, J. Costa and S. Wolynec, J. Biomed. Mater. Res. (2002) 664-672.

[26] S.Y. Yu and J.R. Scully, Corrosion 53 (1997) 965-976. 